\title{
Anthranilic Diamide Insecticides Delivered via Multiple Approaches to Control Vegetable Pests: A Case Study in Snap Bean
}

\author{
Rebecca A. Schmidt-Jeffris ${ }^{1}$ and Brian A. Nault \\ Cornell University, New York State Agricultural Experiment Station, 630 W. North St., Geneva, NY 14456 (schmidt-jeffris@cornell.edu; \\ ban6@cornell.edu) and ${ }^{1}$ Corresponding author, e-mail: schmidt-jeffris@cornell.edu
}

Received 10 July 2016; Accepted 11 September 2016

\begin{abstract}
Many vegetable insect pests are managed using neonicotinoid and pyrethroid insecticides. Unfortunately, these insecticides are toxic to many bees and natural enemies and no longer control some pests that have developed resistance. Anthranilic diamide insecticides provide systemic control of many herbivorous arthropod pests, but exhibit low toxicity to beneficial arthropods and mammals, and may be a promising alternative to neonicotinoids and pyrethroids. Anthranilic diamides may be delivered to vegetable crops via seed, in-furrow, or foliar treatments; therefore, it would be desirable to identify which application method provides high levels of pest control while minimizing the amount of active ingredient. As a case study, chlorantraniliprole and cyantraniliprole applied via the methods listed above were evaluated for managing seedcorn maggot, Delia platura (Meigen) (Diptera: Anthomyiidae), and European corn borer, Ostrinia nubilalis (Hübner) (Lepidoptera: Crambidae), in snap bean. Chlorantraniliprole and cyantraniliprole delivered as seed and in-furrow treatments reduced $D$. platura damage to the same level as the standard neonicotinoid seed treatment. Both diamides applied via all three methods significantly reduced $O$. nubilalis damage, but only the foliar application provided similar control as the standard pyrethroid spray. Results from laboratory bioassays revealed that both diamides applied as seed and in-furrow treatments caused high $O$. nubilalis neonate mortality up to $44 \mathrm{~d}$ after application. While the diamides provided equivalent control of these pests as the neonicotinoid and pyrethroid standards when applied in the same manner, chlorantraniliprole delivered as a seed treatment showed the most promise for managing both pests.
\end{abstract}

Key words: Delia platura, Ostrinia nubilalis, Phaseolus vulgaris, chlorantraniliprole, cyantraniliprole

Many insect pests of vegetables are managed using insecticides applied either at planting or as foliar sprays. Insecticide-treated seeds and in-furrow treatments are frequently used to protect certain vegetable crops from pests that attack germinating seeds and seedlings, while foliar applications protect crop foliage and fruiting structures (Hutchison et al. 2004, Foster and Flood 2005). Neonicotinoid insecticides are the dominant choice for vegetable seed treatments because they effectively control a number of important seedling pests via systemic activity. Pyrethroid insecticides are commonly used as foliar sprays because they have quick knockdown and broad-spectrum activity against foliar and fruit-feeding pests (Hutchison et al. 2004, Foster and Flood 2005, Reiners and Seaman 2015). While these insecticide classes and delivery approaches have been effective in vegetable insect pest management, neonicotinoids and pyrethroid insecticides negatively impact beneficial organisms and also have had environmental problems.

Negative effects of neonicotinoids on bees and other pollinators have been documented (Desneux et al. 2007, Decourtye and Devillers 2010, Goulson 2013, Godfray et al. 2014, Bonmatin et al.
2015, Pisa et al. 2015). Natural enemies (e.g., lacewings, predatory mites, parasitoids, ground beetles; Desneux et al. 2007, Beers and Schmidt 2014, Douglas et al. 2015, Pisa et al. 2015) and other beneficial organisms (nonbee pollinators, earthworms; Pisa et al. 2015) also have been shown to be susceptible to neonicotinoids. In some systems, neonicotinoid applications have disrupted biological control to the point of causing pest flare-ups or decreased yield (Beers et al. 2005, Douglas et al. 2015). Neonicotinoids have shown potential to contaminate surface and ground water (Bonmatin et al. 2015), and can harm nontarget wildlife, including mammals, birds, and fish (Goulson 2013, Gibbons et al. 2015). Moreover, important vegetable pests have developed resistance to neonicotinoids, including Colorado potato beetle, Leptinotarsa decemlineata (Say) (Alyokhin et al. 2007, Huseth et al. 2015b), and sweetpotato whitefly Bemisia tabaci (Gennadius) (Houndété et al. 2010).

Pyrethroids have had similar problems. Although neonicotinoids recently have received a great deal of attention for harming bees, acute toxicity of pyrethroids on bees has also been demonstrated (Smith and Stratton 1986, Theiling and Croft 1988, Inglesfield 
1989). Pyrethroids also cause acute and sublethal effects on many natural enemies, including predatory mites, ladybird beetles, and parasitoid wasps (Hull and Starner 1983, Theiling and Croft 1988, Croft 1990, Desneux et al. 2007, Beers and Schmidt 2014), and are considered to be the most toxic group of pesticides in terms of harming natural enemies (Croft 1990). Spider mite outbreaks in a variety of crops have been attributed to pyrethroid use (Gerson and Cohen 1989). Nontarget effects on aquatic animals, including invertebrates (Anderson 1982, Antwi and Reddy 2015) and fish (Haya 1989), also have been reported. Vegetable pests such as diamondback moth, Plutella xylostella (L.) (Liu et al. 1981), Helicoverpa armigera (Hübner) (Kranthi et al. 2001), corn earworm, H. zea (Boddle) (Jacobson et al. 2009), onion thrips, Thrips tabaci (Linderman) (Shelton et al. 2003), and B. tabaci (Houndété et al. 2010) have been documented as resistant to pyrethroids. Insecticides with alternative modes of action are needed to make advancements in vegetable insect pest management, but without the negative attributes associated with neonicotinoids and pyrethroids.

Anthranilic diamide insecticides may be the most promising alternative to neonicotinoids and pyrethroids for managing many vegetable insect pests. Anthranilic diamides belong to IRAC Group 28 and are ryanodine receptor modulators (Jeanguenat 2013). These insecticides are systemic and have long-lasting residues (Jeanguenat 2013, Barry et al. 2015, Huseth et al. 2015a). They are considered to have a moderate to narrow spectrum of activity against pests, targeting the ryanodine receptors of lepidopterans, but also some species of flies, true bugs, and beetles (DuPont 2008, Jeanguenat 2013). Feeding is the primary route of exposure (Yu 2015). In addition to the acute effects of muscle dysfunction and paralysis, chlorantraniliprole quickly suppresses pest feeding, which reduces damage (Hannig et al. 2009, Yu 2015). Anthranilic diamides also have low toxicity against many beneficial organisms, including honey bees (Apis mellifera L.), bumble bees (Bombus terrestris (L.), B. impatiens Cresson), parasitoid wasps (Eretmocerus eremicus Rose and Zolnerowich, Trichogramma dendrolimi (Matsumura)), ladybird beetles (Coccinella septempunctata L., Adalia bipunctata L.), lacewings (Chrysoperla carnea (Stephens)), predatory mites (Typhlodromus pyri Scheuten, Amblyseius andersoni (Chant)), and predatory hemipterans (Orius insidiosus (Say), Anthocoris nemoralis (F.)) (Dinter et al. 2008a, b, 2012; Gradish et al. 2009; Brugger et al. 2010; Gradish et al. 2010; Larson et al. 2012; Dinter and Samel 2014; Whalen et al. 2016). Selectivity is attributed to molecular differences in ryanodine receptors between insect orders and species within an order, resulting in different target site selectivity between groups (Wang et al. 2012).

Characteristics of the anthranilic diamides are ideal for atplanting delivery approaches like seed treatments and in-furrow applications to manage seedling pests, but also as foliar applications to manage foliage- and fruit-feeding pests. Anthranilic diamides such as chlorantraniliprole and cyantraniliprole are registered in the United States for controlling many agricultural crop pests and they may be applied as seed treatments, in-furrow treatments, and foliar sprays. For example, chlorantraniliprole-treated rice seed has been successful in controlling rice pests like the rice water weevil, Lissorhoptrus oryzophilus Kuschel, and sugarcane borer, Diatraea saccharalis (F.) (Lanka et al. 2013a, b, Lanka 2014, Sidhu et al. 2014). Chlorantraniliprole also has been successfully used in drip chemigation for H. zea control (Kuhar et al. 2010). Cyantraniliprole applied as an in-furrow treatment controlled beet armyworm, Spodoptera exigua (Hübner), cabbage looper, Trichoplusia ni (Hübner), and B. tabaci in broccoli (Natwick 2012a) and in lettuce (Natwick 2012b). Cyantraniliprole also reduced L. decemlineata and potato leafhopper, Empoasca fabae (Harris), populations in potato when applied as a seed treatment or in-furrow (Groves et al. 2013). Both anthranilic diamides have been applied in-furrow to reduce seedcorn maggot, Delia platura (Meigen), damage in cantaloupe (Palumbo 2011) and were also effective as seed treatments for controlling fall armyworm, S. frugiperda (J.E. Smith), in soybean (Thrash et al. 2013). Foliar applications of both pesticides have demonstrated efficacy against several pests, including $S$. frugiperda, eggplant fruit and shoot borer, Leucinodes orbonalis (Guenée), codling moth, Cydia pomonella (L.), B. tabaci, European corn borer, Ostrinia nubilalis (Hübner), and H. armigera (Hardke et al. 2011, Rajavel et al. 2011, Pluciennik 2012, Caballero et al. 2015, Huseth et al. 2015a, Younas et al. 2016). More studies are needed to examine the efficacy of anthranilic diamides against important vegetable insect pests, but also to determine which application method provides the greatest level of control while minimizing the amount of active ingredient.

We conducted a case study in snap bean, Phaseolus vulgaris L. that evaluated chlorantraniliprole and cyantraniliprole delivered via multiple approaches for managing two major insect pests, D. platura and O. nubilalis. Delia platura larvae feed on germinating seeds and seedlings, resulting in either death, crop stunting, or a delay in pod maturity (Flood and Wyman 2005). This pest is almost exclusively managed with thiamethoxam seed treatment in snap bean (Cruiser 5FS, Syngenta Crop Protection, Greensboro, NC). Applications of chlorantraniliprole and cyantraniliprole as seed treatments and in-furrow treatments were effective against $D$. platura in cantaloupe in Arizona (Palumbo 2011), but it is not known how well they might perform against this pest in snap bean. Thus, we compared efficacy of both diamides when applied as seed treatments and in-furrow treatments against $D$. platura. Snap bean is vulnerable to $O$. nubilalis larval damage later in the season, around bloom to early-pod stage (Flood and Wyman 2005). Larvae begin feeding on the foliage, but eventually move into pods and stems (Dively and McCully 1979, Sanborn et al. 1982). Pod infestation at harvest results in contamination of snap bean grown for processing, which has caused snap bean processors to implement very low podcontamination thresholds for this pest (Dively and McCully 1979, Sanborn et al. 1982, Eckenrode and Webb 1989). Consequently, one to two prophylactic foliar applications of bifenthrin or other pyrethroids are applied to each field beginning at bloom or early pod formation (Flood and Wyman 2005). Foliar applications of chlorantraniliprole and cyantraniliprole successfully managed $O$. nubilalis in snap bean in New York (Huseth et al. 2015a), but it is not known whether the same results could be achieved by delivering these insecticides as seed and in-furrow treatments. Thus, we compared efficacy of both diamides when delivered as seed, in-furrow and foliar treatments against $O$. nubilalis.

In addition to comparing the efficacy of chlorantraniliprole and cyantraniliprole administered via seed, in-furrow and foliar treatments for reducing damage by D. platura and O. nubilalis in field studies, we also assessed mortality of $O$. nubilalis larvae after varying exposures to diamide residues in laboratory bioassays. We hypothesized that both chemistries applied at-planting via either seed treatments or in-furrow treatments would provide levels of protection against these pests equivalent to the industry standards. If the seed treatment effectively controls both pests, this option would have considerable environmental and economic benefits, as management could be achieved with decreased applicator handling, reduced-risk materials, and lower or equal amounts of active ingredient. 


\section{Materials and Methods}

Field experiments and laboratory bioassays were conducted over a 3 -yr period. All studies were conducted in snap bean fields in New York, USA.

\section{Field Locations and Planting}

In 2009, the experiment was performed at a New York State Agricultural Experiment Station (NYSAES) research farm near Geneva, NY $\left(42.865500^{\circ},-77.029667^{\circ}\right)$. The 2010 study was conducted on the same NYSAES research farm and in a commercial field southeast of LeRoy, NY (42.925205, -77.966045). The final experiment in 2011 occurred on a NYSAES research farm $\left(42.866664^{\circ},-77.029784^{\circ}\right)$.

All fields were planted with a tractor-mounted cone seeder at 23 seeds per meter. In 2009 and 2011, cv. 'Hystyle' was used; in 2010, cv. 'Caprice' was planted in both LeRoy and Geneva. The planting dates were 26 May 2009, 21 May 2010 (Geneva), 27 May 2010 (LeRoy), and 3 June 2011. All seeds were treated with captan (Captan 400, Bayer CropScience, Research Triangle Park, NC) in 2009 and 2010, or thiram (Thiram 50 WP, Bayer CropScience) in 2011 to control seedling diseases. Plots consisted of two 6.1-m-long rows spaced $0.76 \mathrm{~m}$ apart and were flanked by two rows of bare ground and another 3-m section of bare ground between plots within rows.

\section{Pesticide Applications}

Various formulations and rates of chlorantraniliprole and cyantraniliprole administered as seed treatments, in-furrow or foliar applications (Table 1) were compared with industry standards (thiamethoxam seed treatment and a foliar application of a pyrethroid) and an untreated control. In 2009 and 2010 there were 12 treatments and an untreated control and in 2011 there were 11 treatments and an untreated control; there were five replicates of each treatment each year.

\section{Seed Treatments}

In 2009, chlorantraniliprole and cyantraniliprole were applied to snap bean seeds using a film coating technique with Disco A (Incotec Inc., Salinas, CA) film coating polymer and water binder (1:1) in the Seed Science and Technology Laboratory at NYSAES. In 2010 seeds were commercially treated by Incotec Inc., Salinas, California. To distinguish between the two different formulations of chlorantraniliprole applied at $182 \mu \mathrm{g} \mathrm{AI} / \mathrm{seed}$ in the 2010 trials, DPX-E2Y45 will be referred to as chlorantraniliprole(1) and DPX-E2Y45 + YX860 will be referred to as chlorantraniliprole(2) (Table 1). Seed treatments were not evaluated in 2011.

\section{In-Furrow Applications}

In-furrow treatments were applied using a $\mathrm{CO}_{2}$-pressured sprayer delivering spray at $276 \mathrm{kPa}$ directed through a single, flat-fan nozzle

Table 1. Insecticides used in field experiments, including active ingredient, application method, rate, and year included in the study

\begin{tabular}{|c|c|c|c|c|c|}
\hline Chemical group & Active ingredient (AI) & Trade name or experimental number & Application $\operatorname{method}^{a}$ & Rate $^{b}$ & Year \\
\hline \multirow[t]{2}{*}{ Pyrethroids } & Bifenthrin & Brigade $\mathrm{EC}^{c}$ & $\mathrm{~F}$ & 61 & 2010,2011 \\
\hline & Zeta-Cypermethrin + bifenthrin & Hero $1.24 \mathrm{EC}^{c}$ & $\mathrm{~F}$ & $11+33$ & 2009 \\
\hline Neonicotinoids & Thimethoxam & Cruiser $5 \mathrm{FS}^{d}$ & ST & 91 & 2009,2010 \\
\hline \multirow[t]{12}{*}{ Diamides } & Chlorantraniliprole & Dermacor X-100 ${ }^{e}$ & ST & 111 & 2009 \\
\hline & & & & 334 & 2009 \\
\hline & & DPX-E2Y45 $5^{e}$ & ST & 91 & 2010 \\
\hline & & & & 182 & 2010 \\
\hline & & & & 273 & 2010 \\
\hline & & $\mathrm{DPX}-\mathrm{E} 2 \mathrm{Y} 45+\mathrm{YX} 860^{e}$ & ST & 182 & 2010 \\
\hline & & Coragen $1.87 \mathrm{SC}^{e}$ & IF & 49 & 2010,2011 \\
\hline & & & & 74 & 2009-2011 \\
\hline & & & & 102 & 2011 \\
\hline & & & $\mathrm{F}$ & 49 & 2010,2011 \\
\hline & & & & 74 & 2009-2011 \\
\hline & & & & 102 & 2011 \\
\hline \multirow[t]{12}{*}{ Diamides } & Cyantraniliprole & HGW86-44 60FS & ST & 111 & 2009 \\
\hline & & & & 334 & 2009 \\
\hline & & DPX HGW86 & ST & 91 & 2010 \\
\hline & & & & 273 & 2010 \\
\hline & & HGW86-402 $20 \mathrm{SC}^{e}$ & IF & 98 & 2009 \\
\hline & & & & 197 & 2010 \\
\hline & & HGW86 20SC ${ }^{e}$ & IF & 150 & 2011 \\
\hline & & HGW86 10OD ${ }^{e}$ & $\mathrm{~F}$ & 98 & 2009 \\
\hline & & $\mathrm{HGW}_{8} 10 \mathrm{SE}^{e}+\mathrm{MSO}^{f}$ & $\mathrm{~F}$ & 49 & 2011 \\
\hline & & & & 99 & 2011 \\
\hline & & & & $99^{g}$ & 2011 \\
\hline & & & & 150 & 2011 \\
\hline
\end{tabular}

${ }^{a}$ Seed treatment (ST), in-furrow (IF), foliar (F).

${ }^{b}$ Seed treatments ( $\mu \mathrm{g} \mathrm{AI} /$ seed) or in-furrow or foliar applications (g AI/ha).

${ }^{\mathrm{c}}$ FMC Corporation, Agricultural Products Group, Philadelphia, PA.

d Syngenta Crop Protection, LLC, Greensboro, NC.

${ }^{\mathrm{e}}$ E. I. du Pont De Nemours and Co., Wilmington, DE.

${ }^{\mathrm{f}}$ Methylated seed oil adjuvant, included at a rate of $0.25 \% \mathrm{v}: \mathrm{v}$.

$\mathrm{g}$ This treatment did not include MSO. 
in a $7.6 \mathrm{~cm}$ band in the furrow immediately after the seed was planted and before the furrow was closed. This sprayer was mounted to the cone seeder. The nozzles used were 8004VS TeeJet in 2009 or 11004VK TeeJet in 2010 and 2011 (Spraying Systems, Wheaton, IL). Spray volumes were 318 liter/ha (2009) and 346 liter/ha (2010-2011).

\section{Foliar Applications}

Foliar treatments were made using a $\mathrm{CO}_{2}$-pressurized, backpack sprayer that delivered 215 (2009-2010) or 177 liter/ha (2011) at $276 \mathrm{kPa}$ through three hollow-cone nozzles in which the center nozzle was directed over the top of the row (TXA8001VK, Spraying Systems) and the outer nozzles were on drop pipes (TXB8001VK, Spraying Systems) directed into the side of the canopy. Applications were administered once per season, during early-pod development, on 16 July 2009, 14 July 2010 in Geneva, 19 July 2010 in LeRoy, and 18 July 2011.

\section{Insect Damage Assessment \\ Delia platura}

Immediately after seeds were planted, a combination of bone and meat meal was placed in a narrow band over the left-hand row (the right row was for O. nubilalis infestation, see below) of each replicate to attract $D$. platura females to the test site and to concentrate their eggs near seeds within the row, a common practice in D. platura trials (Reid 1940, Judge and McEwen 1970, Vea and Eckenrode 1976, Palumbo 2011). The rate of bone and meat meal was $320 \mathrm{~g}$ per $6.1 \mathrm{~m}$ row. This was done to increase D. platura pressure in the trial to mimic a worst-case scenario that occurs in commercial snap bean fields treated with animal manure. Damage by $D$. platura was assessed only in treatments applied at planting (i.e., excluded all foliar spray treatments). After most of the snap bean plants emerged (12-15 d after planting), the number of germinating seeds and seedlings that were still infested or recently damaged by D. platura was recorded from 25 randomly selected germinating seeds and seedlings. Damage included holes and tunnels made in the lower stem and cotyledon leaves, or the absence of a well-defined apical meristem and true leaves (only cotyledon leaves remained). Delia platura damage was not recorded in 2011.

\section{Ostrinia nubilalis}

Because natural O. nubilalis pressure in snap bean at the experiment sites is typically low, plots were infested with $O$. nubilalis neonates obtained from French Agricultural Research Inc. (Lamberton, MN). A 3-m section within the right-hand row of each plot was infested with neonates in all experiments. Releases were performed by holding pieces of wax paper containing the neonates above the plants and gently tapping them uniformly over the row. For each trial, two releases were made within a short period. On 16 July 2009, two releases of 1,000 neonates each were made $5 \mathrm{~h}$ apart. In the 2010 Geneva trial, $\sim 1,000$ neonates were released on 14 July and 2,000 released on 15 July. In LeRoy, $\sim 1,000$ neonates were released on both 19 and 20 July. The plots in the 2011 trial were infested with 1,000 neonates on both 15 and 18 July. Plots designated to receive a foliar treatment were sprayed in between releases (2009-2010) or after the second release (2011).

The number of snap bean plants and market-sized pods damaged or not damaged by $O$. nubilalis larvae was recorded from the infested section of each plot at harvest. Harvest occurred on 31 July 2009, 29 July 2010 (Geneva), 2 Aug 2010 (LeRoy), and 8 Aug 2011. All plants were removed by hand from the infested section of each plot. Pods were individually removed from plants and inspected for damage. Pods and plants were considered damaged if an entry hole with feeding damage was found; in many cases the larva was also present, but this information was not recorded separately.

\section{Bioassays to Determine Residual Activity Against $O$. nubilalis Larvae \\ 2009}

Two laboratory bioassays were conducted prior to harvest in which the efficacy of all at-plant treatments was evaluated for O. nubilalis neonate mortality. The first bioassay was initiated during bloom (9 July) and the second during early-pod development (16 July). On each date, a total of eight leaflets was collected from the top half of the canopy in selected treatments within replications 1 and 4 . A single leaflet, abaxial side facing upwards, was placed into a $10.2-\mathrm{cm}-$ diameter Petri dish (Fisher Scientific, Waltham, MA) lined with moistened filter paper. Fifteen O. nubilalis neonates were transferred into each Petri dish. Each treatment was replicated eight times; replicates consisted of a single Petri dish with a leaflet and neonates. Petri dishes were maintained in an environmental chamber at $24^{\circ} \mathrm{C}$ and $60 \%$ relative humidity. After $96 \mathrm{~h}$, the number of live and dead larvae was recorded.

\section{1}

Two bioassays were conducted to assess the residual activity of chlorantraniliprole applied at a rate of $74 \mathrm{~g} \mathrm{AI} /$ ha as either an infurrow or foliar treatment. Bioassays were initiated during bloom (22 July) and early pod development (29 July). The bioassay was set up as described for the 2009 bioassay study, except samples were collected from all replicates and the bloom assay and early-pod assay had eight and five subsamples per replicate, respectively.

\section{Data Analyses}

The experimental design for all field trials was a randomized complete block design (RCBD) and treatments were replicated five times. Field-collected data were analyzed using a generalized linear mixed model (SAS PROC GLIMMIX, 2016; SAS Institute, Cary, $\mathrm{NC}$ ), specifying a binomial distribution for damage data (damaged plants/total plants, damaged pods/total pods, damaged germinating seeds and seedlings/total germinating seeds and seedlings). Replicate was treated as a random effect.

The 2009 bioassay data were analyzed similarly (binomial distribution, dead larvae/total larvae), but replicate was not included in the model (this design was a completely randomized design, not $\mathrm{RCBD}$, as the replicates did not correspond to field replicates). The 2011 bioassay data were analyzed using an RCBD, specifying replicate as a random effect; the replicates in this bioassay corresponded to the replicates (blocking factor) in the field.

For all field and bioassay analyses, treatments were compared using least-squared means at $P<0.05$. Individual treatments were always used as the main factor; type of application method was not analyzed separately. The difference in rates and formulations for many of the treatments between seed treatment, in-furrow, and foliar applications did not allow for this statistical comparison.

\section{Results}

\section{Delia platura}

In 2009, all insecticide treatments significantly reduced the level of D. platura damage relative to the untreated control. Chlorantraniliprole and cyantraniliprole provided an equivalent 
level of protection as the industry standard, thiamethoxam seed treatment (Table 2). There were no performance differences among the anthranilic diamide active ingredients, rates, or methods of application.

In 2010 in Geneva, most of the insecticide treatments significantly reduced the level of $D$. platura damage relative to the untreated control (Table 3). Middle rates of both chlorantraniliprole ( $1 \& 2$ ) seed treatments $(182 \mu \mathrm{g} \mathrm{AI} / \mathrm{seed})$, the high rate of cyantraniliprole seed treatment $(273 \mu \mathrm{g} \mathrm{AI} /$ seed $)$, and the high rate of the chlorantraniliprole in-furrow treatment $(102 \mathrm{~g} \mathrm{AI} / \mathrm{ha})$ provided the same level of protection against $D$. platura as thiamethoxam seed treatment (Table 3). The lowest rate of chlorantraniliprole seed treatment $(91 \mu \mathrm{g} \mathrm{AI} / \mathrm{seed})$ and low rate of chlorantraniliprole infurrow application $(74 \mathrm{~g} \mathrm{AI} / \mathrm{ha}$ ) failed to protect the snap bean crop from D. platura damage (Table 3).

Table 2. Mean percentage ( \pm SE) of snap bean germinating seeds or seedlings (out of $n=25$ ) damaged by $D$. platura in field plots that received insecticide seed treatments and in-furrow insecticide applications in Geneva, NY, in 2009

\begin{tabular}{lrcc}
\hline Treatment & Rate $^{a}$ & $\begin{array}{c}\text { Application } \\
\text { type }\end{array}$ & $\begin{array}{l}\text { Percent germinating } \\
\text { seeds or seedlings } \\
\text { damaged by D. platura }\end{array}$ \\
\hline Untreated control & - & - & $55.2 \pm 5.3 \mathrm{a}$ \\
Thiamethoxam & 91 & ST & $12.0 \pm 4.2 \mathrm{~b}$ \\
Chlorantraniliprole & 111 & ST & $8.8 \pm 1.5 \mathrm{~b}$ \\
Chlorantraniliprole & 334 & ST & $16.0 \pm 2.5 \mathrm{~b}$ \\
Cyantraniliprole & 111 & ST & $13.6 \pm 3.9 \mathrm{~b}$ \\
Cyantraniliprole & 334 & ST & $12.8 \pm 5.6 \mathrm{~b}$ \\
Chlorantraniliprole & 74 & IF & $16.8 \pm 5.4 \mathrm{~b}$ \\
Chlorantraniliprole & 102 & IF & $17.6 \pm 5.2 \mathrm{~b}$ \\
Cyantraniliprole & 98 & IF & $12.8 \pm 3.7 \mathrm{~b}$ \\
Cyantraniliprole & 197 & IF & $16.0 \pm 4.6 \mathrm{~b}$ \\
$F_{9,36}$ & & & 11.91 \\
$P$ & & & $<0.0001$ \\
\hline
\end{tabular}

${ }^{a}$ Seed treatments ( $\left.\mu \mathrm{g} \mathrm{AI} / \mathrm{seed}\right)$ or in-furrow applications (g AI/ha).

${ }^{b}$ Seed treatment (ST), in-furrow (IF).
In 2010 in LeRoy, several of the insecticide treatments significantly reduced the level of $D$. platura damage compared with the untreated control (Table 3). The chlorantraniliprole(2) seed treatment $(182 \mu \mathrm{g} \mathrm{AI} / \mathrm{seed})$, the high rate of the cyantraniliprole seed treatments ( $273 \mu \mathrm{g} \mathrm{AI} / \mathrm{seed})$, and both rates of the chlorantraniliprole in-furrow treatments (74 and $102 \mathrm{~g} \mathrm{AI} / \mathrm{ha}$ ) provided an equivalent level of protection against D. platura as thiamethoxam. Neither of the chlorantraniliprole(1) seed treatment rates (91 and $182 \mu \mathrm{g} \mathrm{AI} / \mathrm{seed}$ rate) protected the snap bean crop from D. platura damage (Table 3).

Our results over $2 \mathrm{yr}$ indicated that chlorantraniliprole and cyantraniliprole applied as either a seed treatment or in-furrow treatment could replace thiamethoxam seed treatment for protecting snap bean from $D$. platura damage.

\section{Ostrinia nubilalis}

In 2009, a majority of the insecticide treatments significantly reduced the percentage of plants and pods damaged by O. nubilalis compared with the untreated control (Table 4). The high rate of chlorantraniliprole seed treatment ( $334 \mu \mathrm{g} \mathrm{AI} / \mathrm{seed})$ and foliar applications of chlorantraniliprole and cyantraniliprole resulted in the lowest percent of O. nubilalis-damaged plants and pods, which were similar to those in the industry standard, zeta-cypermethrin + bifenthrin (Table 4). The low rate of cyantraniliprole infurrow treatment (98 g AI/ha) and the thiamethoxam seed treatment did not reduce O. nubilalis damage levels compared with the untreated control (Table 4). All other treatments provided an intermediate level of protection.

In 2010 in Geneva, several insecticide treatments significantly reduced plant and pod damage relative to the untreated control (Table 5). The best performing treatments were foliar applications of chlorantraniliprole and cyantraniliprole, which provided the same protection against $O$. nubilalis damage to plants and pods as that provided by the industry standard, bifenthrin (Table 5). Other treatments that significantly reduced plant and pod damage included the high in-furrow rate of chlorantraniliprole (102 $\mathrm{g} \mathrm{AI} / \mathrm{ha}$ ) followed by the middle and high rates of chlorantraniliprole(1) seed treatments (182 and $273 \mu \mathrm{g} \mathrm{AI} /$ seed) (Table 5). Treatments that failed to reduce levels of $O$. nubilalis plant and pod damage relative to the

Table 3. Mean percentage ( \pm SE) of snap bean germinating seeds or seedlings (out of $n=25$ ) damaged by $D$. platura in field plots that received insecticide seed treatments and in-furrow insecticide applications in Geneva, NY, and LeRoy, NY, in 2010

\begin{tabular}{|c|c|c|c|c|}
\hline \multirow[t]{2}{*}{ Treatment } & \multirow[t]{2}{*}{ Rate $^{a}$} & \multirow[t]{2}{*}{ Application type $\mathrm{e}^{b}$} & \multicolumn{2}{|c|}{ Percent germinating seeds or seedlings damaged by $D$. platura } \\
\hline & & & Geneva & LeRoy \\
\hline Untreated control & - & - & $32.8 \pm 4.1 \mathrm{a}$ & $28.8 \pm 3.2 \mathrm{a}$ \\
\hline Thiamethoxam & 91 & $\mathrm{ST}$ & $8.8 \pm 2.7 \mathrm{de}$ & $9.6 \pm 3.2 \mathrm{de}$ \\
\hline Chlorantraniliprole & 91 & ST & $24.8 \pm 6.1 \mathrm{ab}$ & $26.4 \pm 3.7 \mathrm{ab}$ \\
\hline Chlorantraniliprole $(1)^{c}$ & 182 & ST & $11.2 \pm 1.5 \mathrm{cde}$ & $22.4 \pm 5.7 \mathrm{abc}$ \\
\hline Chlorantraniliprole & 273 & ST & $18.4 \pm 3.2 \mathrm{bc}$ & $18.4 \pm 4.1 \mathrm{a}-\mathrm{d}$ \\
\hline Chlorantraniliprole $(2)^{c}$ & 182 & ST & $6.4 \pm 1.6 \mathrm{e}$ & $8.8 \pm 1.5 \mathrm{e}$ \\
\hline Cyantraniliprole & 91 & ST & $16.8 \pm 3.9 \mathrm{bcd}$ & $17.6 \pm 4.1 \mathrm{bcd}$ \\
\hline Cyantraniliprole & 273 & ST & $8.0 \pm 4.2 \mathrm{e}$ & $13.6 \pm 3.0 \mathrm{cde}$ \\
\hline Chlorantraniliprole & 74 & IF & $26.4 \pm 3.0 \mathrm{ab}$ & $13.6 \pm 2.7 \mathrm{cde}$ \\
\hline Chlorantraniliprole & 102 & IF & $13.6 \pm 2.7 \mathrm{cde}$ & $12.0 \pm 3.1 \mathrm{de}$ \\
\hline$F_{9,26}$ & & & 6.42 & 3.99 \\
\hline$P$ & & & $<0.0001$ & 0.0013 \\
\hline
\end{tabular}

\footnotetext{
${ }^{a}$ Seed treatments ( $\mu \mathrm{g} \mathrm{AI} /$ seed) or in-furrow applications (g AI/ha).

${ }^{b}$ Seed treatment (ST), in-furrow (IF).

${ }^{c}$ To distinguish between the two different formulations of chlorantraniliprole applied at $182 \mu \mathrm{g} \mathrm{AI} / \mathrm{seed}$ in the 2010 trials, DPX-E2Y45 will be referred to as chlorantraniliprole(1) and DPX-E2Y45 + YX860 will be referred to as chlorantraniliprole(2).
} 
Table 4. Mean percentage ( \pm SE) of snap bean plants and pods damaged by $O$. nubilalis in field plots that received insecticides delivered via seed treatments, in-furrow treatments, and foliar sprays in Geneva, NY, in 2009

\begin{tabular}{|c|c|c|c|c|c|c|}
\hline \multirow[t]{2}{*}{ Treatment } & \multirow[t]{2}{*}{ Rate $^{a}$} & \multirow[t]{2}{*}{ Application type $^{b}$} & \multicolumn{4}{|c|}{ Percent O. nubilalis damage } \\
\hline & & & $n$ plants & Plants & $n$ pods & Pods \\
\hline Untreated control & - & - & 272 & $17.5 \pm 4.4 \mathrm{a}$ & 1,717 & $4.6 \pm 1.5 \mathrm{a}$ \\
\hline Thimethoxam & 91 & ST & 324 & $14.9 \pm 3.6 \mathrm{ab}$ & 2,379 & $4.7 \pm 0.6 \mathrm{a}$ \\
\hline Chlorantraniliprole & 111 & ST & 361 & $4.3 \pm 1.9 c$ & 2,473 & $1.8 \pm 0.2 \mathrm{~cd}$ \\
\hline Chlorantraniliprole & 334 & ST & 363 & $0.6 \pm 0.4 \mathrm{e}$ & 2,547 & $0.8 \pm 0.3 \mathrm{e}$ \\
\hline Cyantraniliprole & 111 & ST & 328 & $9.4 \pm 6.8 b$ & 2,102 & $2.7 \pm 0.4 b c$ \\
\hline Cyantraniliprole & 334 & ST & 279 & $3.3 \pm 0.7 \mathrm{~cd}$ & 2,137 & $2.0 \pm 0.7 \mathrm{bcd}$ \\
\hline Chlorantraniliprole & 74 & IF & 292 & $10.8 \pm 6.2 \mathrm{~b}$ & 2,352 & $2.9 \pm 0.8 b$ \\
\hline Chlorantraniliprole & 102 & IF & 295 & $2.8 \pm 1.5 \mathrm{~cd}$ & 2,234 & $1.8 \pm 0.4 \mathrm{~cd}$ \\
\hline Cyantraniliprole & 98 & IF & 321 & $18.9 \pm 1.8 \mathrm{a}$ & 2,078 & $4.3 \pm 1.5 \mathrm{a}$ \\
\hline Cyantraniliprole & 197 & IF & 309 & $3.5 \pm 1.5 \mathrm{~cd}$ & 2,192 & $1.6 \pm 1.0 \mathrm{~d}$ \\
\hline Zeta-Cypermethrin + bifenthrin & $11+33$ & F & 311 & $1.7 \pm 1.0 \mathrm{cde}$ & 2,459 & $0.2 \pm 0.1 \mathrm{f}$ \\
\hline Chlorantraniliprole & 74 & F & 289 & $0.8 \pm 0.8 \mathrm{de}$ & 2,184 & $0.1 \pm 0.1 \mathrm{f}$ \\
\hline Cyantraniliprole & 98 & F & 277 & $0.0 \pm 0.0 \mathrm{e}$ & 1,853 & $0.2 \pm 0.1 \mathrm{f}$ \\
\hline$F_{12,48}$ & & & & 12.63 & & 19.19 \\
\hline$P$ & & & & $<0.0001$ & & $<0.0001$ \\
\hline
\end{tabular}

${ }^{a}$ Seed treatments ( $\mu \mathrm{g} \mathrm{AI} / \mathrm{seed}$ ) or in-furrow or foliar applications (g AI/ha).

${ }^{b}$ Seed treatment (ST), in-furrow (IF), foliar (F).

Table 5. Mean percentage $( \pm S E$ ) of snap bean plants and pods damaged by $O$. nubilalis in field plots that received insecticides delivered via seed treatments, in-furrow treatments, and foliar sprays in Geneva, NY, and LeRoy, NY, in 2010

\begin{tabular}{|c|c|c|c|c|c|c|c|c|c|c|}
\hline \multirow[t]{3}{*}{ Treatment } & \multirow[t]{3}{*}{ Rate $^{a}$} & \multirow{3}{*}{$\begin{array}{l}\text { Application } \\
\text { type }^{b}\end{array}$} & \multicolumn{8}{|c|}{ Percent O. nubilalis damage } \\
\hline & & & \multicolumn{4}{|c|}{ Geneva } & \multicolumn{4}{|c|}{ LeRoy } \\
\hline & & & $n$ plants & Plants & $n$ pods & Pods & $n$ plants & Plants & $n$ pods & Pods \\
\hline Untreated control & - & - & 269 & $45.6 \pm 9.4 b c$ & 2,100 & $11.8 \pm 2.2 b$ & 265 & $28.9 \pm 2.2 \mathrm{a}$ & 2,566 & $5.6 \pm 1.8 \mathrm{a}$ \\
\hline Chlorantraniliprole & 91 & ST & 298 & $51.7 \pm 5.5 \mathrm{bc}$ & 2,484 & $14.7 \pm 2.6 \mathrm{a}$ & 274 & $24.5 \pm 9.8 \mathrm{ab}$ & 2,872 & $4.5 \pm 1.5 \mathrm{a}$ \\
\hline Chlorantraniliprole $(1)^{c}$ & 182 & ST & 249 & $29.4 \pm 10.2 \mathrm{e}$ & 2,047 & $8.3 \pm 2.1 \mathrm{~d}$ & 291 & $18.8 \pm 5.8 \mathrm{~b}$ & 2,345 & $3.4 \pm 1.6 b$ \\
\hline Chlorantraniliprole & 273 & ST & 297 & $23.3 \pm 2.9 \mathrm{e}$ & 2,327 & $7.5 \pm 1.1 \mathrm{~d}$ & 324 & $16.0 \pm 4.6 \mathrm{bc}$ & 3,169 & $2.2 \pm 0.7 \mathrm{c}$ \\
\hline Chlorantraniliprole $(2)^{c}$ & 182 & ST & 326 & $39.9 \pm 10.1 \mathrm{~d}$ & 2,027 & $10.4 \pm 2.8 \mathrm{c}$ & 320 & $17.8 \pm 6.1 b$ & 3,046 & $2.6 \pm 0.6 b c$ \\
\hline Cyantraniliprole & 91 & ST & 240 & $64.9 \pm 6.4 a$ & 1,499 & $15.6 \pm 4.3 \mathrm{a}$ & 309 & $24.1 \pm 10.5 \mathrm{ab}$ & 3,252 & $3.1 \pm 1.4 \mathrm{bc}$ \\
\hline Cyantraniliprole & 273 & ST & 303 & $53.3 \pm 11.0 \mathrm{~b}$ & 2,024 & $13.8 \pm 3.9 \mathrm{a}$ & 302 & $24.0 \pm 5.2 \mathrm{ab}$ & 3,234 & $2.9 \pm 1.2 b c$ \\
\hline Chlorantraniliprole & 74 & IF & 251 & $44.4 \pm 8.2 \mathrm{~cd}$ & 1,984 & $20.4 \pm 7.6 \mathrm{a}$ & 281 & $11.6 \pm 4.0 \mathrm{c}$ & 3,095 & $1.7 \pm 0.2 \mathrm{~d}$ \\
\hline Chlorantraniliprole & 102 & IF & 268 & $14.7 \pm 4.0 \mathrm{f}$ & 2,015 & $3.5 \pm 1.3 \mathrm{e}$ & 331 & $18.0 \pm 8.4 \mathrm{~b}$ & 3,042 & $3.1 \pm 0.9 b c$ \\
\hline Bifenthrin & 61 & $\mathrm{~F}$ & 282 & $1.8 \pm 0.7 \mathrm{~g}$ & 1,947 & $0.2 \pm 0.1 \mathrm{f}$ & 246 & $0.4 \pm 0.4 \mathrm{~d}$ & 2,702 & $0.0 \pm 0.0 \mathrm{e}$ \\
\hline Chlorantraniliprole & 49 & $\mathrm{~F}$ & 279 & $0.7 \pm 0.4 \mathrm{~g}$ & 2,501 & $0.2 \pm 0.2 f$ & 252 & $0.7 \pm 0.7 \mathrm{~d}$ & 2,791 & $0.0 \pm 0.0 \mathrm{e}$ \\
\hline Chlorantraniliprole & 74 & F & 255 & $3.0 \pm 1.1 \mathrm{~g}$ & 2,166 & $0.3 \pm 0.1 \mathrm{f}$ & 275 & $0.0 \pm 0.0 \mathrm{~d}$ & 2,882 & $0.0 \pm 0.0 \mathrm{e}$ \\
\hline$F$ & & & & 34.33 & & 50.78 & & 7.6 & & 11.59 \\
\hline $\mathrm{df}$ & & & & 11,43 & & 11,43 & & 11,44 & & 10,43 \\
\hline$P$ & & & & $<0.0001$ & & $<0.0001$ & & $<0.0001$ & & $<0.0001$ \\
\hline
\end{tabular}

${ }^{a}$ Seed treatments ( $\left.\mu \mathrm{g} \mathrm{AI} / \mathrm{seed}\right)$ or in-furrow or foliar applications ( $\left.\mathrm{g} \mathrm{AI} / \mathrm{ha}\right)$.

${ }^{b}$ Seed treatment (ST), in-furrow (IF), foliar (F).

${ }^{c}$ To distinguish between the two different formulations of chlorantraniliprole applied at $182 \mu \mathrm{g} \mathrm{AI} / \mathrm{seed}$ in the 2010 trials, DPX-E2Y45 will be referred to as chlorantraniliprole(1) and DPX-E2Y45 + YX860 will be referred to as chlorantraniliprole(2).

untreated control were the low rate of chlorantraniliprole seed treatment ( $91 \mu \mathrm{g} \mathrm{AI} / \mathrm{seed})$, both rates of cyantraniliprole seed treatments (91 and $273 \mu \mathrm{g} \mathrm{AI} / \mathrm{seed}$ ) and the low in-furrow rate of chlorantraniliprole (74 g AI/ha).

In 2010 in LeRoy, many insecticide treatments significantly reduced plant and pod damage relative to the untreated control (Table 5). As in the 2010 Geneva study, the best performing treatments included foliar applications of chlorantraniliprole and cyantraniliprole, which provided the same protection against $O$. nubilalis damage to plants and pods as bifenthrin (Table 5). The only treatment that did not reduce levels of O. nubilalis plant or pod damage relative to the untreated control was chlorantraniliprole seed treatment at the low rate $(91 \mu \mathrm{g} \mathrm{AI} /$ seed). Both rates of cyantraniliprole seed treatment (91 and $273 \mu \mathrm{g} \mathrm{AI} / \mathrm{seed}$ ) reduced pod damage, but not plant damage relative to the untreated control.

In 2011 in Geneva, all insecticide treatments significantly reduced plant and pod damage relative to the untreated control, with the exception of the in-furrow application of cyantraniliprole $(150 \mathrm{~g} \mathrm{AI} / \mathrm{ha})$ that did not significantly reduce pod damage (Table 6). The best performing treatments included all foliar applications of chlorantraniliprole and cyantraniliprole, regardless of rate, which provided the same protection against $O$. nubilalis damage to plants and pods as bifenthrin (Table 6). All in-furrow treatments of chlorantraniliprole and cyantraniliprole provided a similar level of reduction in $O$. 
nubilalis damage to plants and pods. The inclusion of MSO as an adjuvant did not increase the efficacy of foliar cyantraniliprole applications.

Overall, results from our 3-yr study indicated that foliar applications of chlorantraniliprole and cyantraniliprole performed as well as bifenthrin and zeta-cypermethrin + bifenthrin for protecting snap bean from O. nubilalis plant and pod damage. The higher rates of chlorantraniliprole seed treatments $(182,273,334 \mu \mathrm{g} \mathrm{AI} /$ seed) and high infurrow rate of chlorantraniliprole (102 $\mathrm{g} \mathrm{AI} / \mathrm{ha})$ also performed quite well, but did not provide the same level of protection as the foliar applications of the anthranilic diamides under such high insect pressure.

\section{Bioassays to Determine Residual Activity Against O. nubilalis Larvae}

Across both at-planting insecticide delivery methods, leaves collected from insecticide-treated plants at bloom ( $44 \mathrm{~d}$ after planting) in 2009 caused higher O. nubilalis mortality than those collected at early pod (51 d after planting) development $(80.1 \pm 1.4 \%$ and $61.5 \pm 1.6 \%$, respectively; $\left.F_{1,126}=72.42, P<0.0001\right)$. At both plant collection dates, all insecticide treatments caused higher mortality than the untreated control. Treatments causing the highest mortality at bloom included the high rate of the chlorantraniliprole seed treatment (334 $\mu \mathrm{g} \mathrm{AI} / \mathrm{seed})$, the low rate of the chlorantraniliprole in-furrow treatment ( $74 \mathrm{~g} \mathrm{AI} / \mathrm{ha})$, and the high rate of the cyantraniliprole in-furrow treatment (197g AI/ha; Table 7). The lowest mortality at bloom occurred in the low rate cyantraniliprole seed treatment $(111 \mu \mathrm{g} \mathrm{AI} / \mathrm{seed})$. At early pod stage, the high rate of chlorantraniliprole seed treatment $(334 \mu \mathrm{g} \mathrm{AI} / \mathrm{seed})$ and high infurrow rate of chlorantraniliprole $(102 \mathrm{~g} \mathrm{AI} / \mathrm{ha})$ caused the highest mortality (Table 7). The lowest mortality occurred in the low rates of chlorantraniliprole and cyantraniliprole seed treatments (both $111 \mu \mathrm{g} \mathrm{AI} / \mathrm{seed})$.

In the 2011 bioassay, the older residues of chlorantraniliprole from insecticide-treated plants also caused less O. nubilalis mortality than the newer residues (Table 8 ). In both collection dates,

Table 6. Mean percentage ( $\pm \mathrm{SE}$ ) of snap bean plants and pods damaged by $O$. nubilalis in field plots that received insecticides delivered via in-furrow treatments and foliar sprays in Geneva, NY, in 2011

\begin{tabular}{|c|c|c|c|c|c|c|}
\hline \multirow[t]{2}{*}{ Treatment } & \multirow[t]{2}{*}{ Rate (g AI/ha) } & \multirow[t]{2}{*}{ Application type ${ }^{a}$} & \multicolumn{4}{|c|}{ Percent O. nubilalis damage } \\
\hline & & & $n$ plants & Plants & $n$ pods & Pods \\
\hline Untreated control & - & - & 304 & $14.7 \pm 2.3 \mathrm{a}$ & 1,498 & $2.0 \pm 0.5 \mathrm{a}$ \\
\hline Chlorantraniliprole & 49 & IF & 337 & $6.0 \pm 2.6 b$ & 2,200 & $1.2 \pm 0.4 b$ \\
\hline Chlorantraniliprole & 74 & IF & 298 & $7.9 \pm 2.9 b$ & 1,924 & $1.0 \pm 0.2 b$ \\
\hline Chlorantraniliprole & 102 & IF & 321 & $5.9 \pm 1.0 \mathrm{~b}$ & 1,733 & $0.8 \pm 0.2 b$ \\
\hline Cyantraniliprole & 150 & IF & 394 & $8.0 \pm 3.5 b$ & 1,921 & $1.5 \pm 0.8 \mathrm{ab}$ \\
\hline Bifenthrin & 61 & $\mathrm{~F}$ & 326 & $0.0 \pm 0.0 \mathrm{c}$ & 1,785 & $0.1 \pm 0.1 \mathrm{c}$ \\
\hline Chlorantraniliprole & 49 & F & 302 & $0.0 \pm 0.0 \mathrm{c}$ & 1,687 & $0.0 \pm 0.0 \mathrm{c}$ \\
\hline Chlorantraniliprole & 74 & F & 312 & $0.0 \pm 0.0 \mathrm{c}$ & 1,726 & $0.0 \pm 0.0 \mathrm{c}$ \\
\hline Cyantraniliprole $+\mathrm{MSO}^{b}$ & 49 & $\mathrm{~F}$ & 330 & $0.3 \pm 0.3 c$ & 1,650 & $0.0 \pm 0.0 \mathrm{c}$ \\
\hline Cyantraniliprole $+\mathrm{MSO}^{b}$ & 99 & F & 292 & $0.0 \pm 0.0 \mathrm{c}$ & 1,600 & $0.0 \pm 0.0 \mathrm{c}$ \\
\hline Cyantraniliprole $+\mathrm{MSO}^{b}$ & 150 & $\mathrm{~F}$ & 332 & $0.6 \pm 0.4 c$ & 1,485 & $0.0 \pm 0.0 \mathrm{c}$ \\
\hline Cyantraniliprole & 99 & $\mathrm{~F}$ & 309 & $0.6 \pm 0.6 \mathrm{c}$ & 1,603 & $0.0 \pm 0.0 \mathrm{c}$ \\
\hline$F$ & & & & 7.83 & & 3.32 \\
\hline df & & & & 8,44 & & 11,44 \\
\hline$P$ & & & & $<0.0001$ & & 0.0022 \\
\hline
\end{tabular}

${ }^{a}$ In-furrow (IF), foliar (F).

${ }^{b}$ Methylated seed oil adjuvant, included at a rate of $0.25 \% \mathrm{v}: \mathrm{v}$.

Table 7. Percentage mortality ( $\pm \mathrm{SE}$ ) of $O$. nubilalis neonates after $96 \mathrm{~h}$ when subjected to leaflets collected from snap bean field plantings treated with insecticides administered as either seed treatments or in-furrow treatments

\begin{tabular}{|c|c|c|c|c|c|c|}
\hline \multirow[t]{2}{*}{ Treatment } & \multirow[t]{2}{*}{ Rate $^{a}$} & \multirow[t]{2}{*}{ Application type ${ }^{b}$} & \multicolumn{2}{|l|}{ Bloom } & \multicolumn{2}{|l|}{ Early pod } \\
\hline & & & $n$ subjects & Percent mortality & $n$ subjects & Percent mortality \\
\hline Untreated control & - & - & 116 & $13.0 \pm 5.0 \mathrm{f}$ & 121 & $8.3 \pm 2.3 \mathrm{f}$ \\
\hline Chlorantraniliprole & 111 & ST & 98 & $61.0 \pm 9.2 \mathrm{~d}$ & 107 & $31.4 \pm 11.1 \mathrm{e}$ \\
\hline Chlorantraniliprole & 334 & ST & 136 & $97.7 \pm 1.3 \mathrm{a}$ & 107 & $90.9 \pm 2.3 \mathrm{a}$ \\
\hline Cyantraniliprole & 111 & ST & 105 & $43.6 \pm 10.0 \mathrm{e}$ & 117 & $27.3 \pm 4.4 \mathrm{e}$ \\
\hline Cyantraniliprole & 334 & ST & 110 & $82.7 \pm 9.1 \mathrm{c}$ & 102 & $54.8 \pm 8.7 \mathrm{~d}$ \\
\hline Chlorantraniliprole & 74 & IF & 92 & $99.0 \pm 1.0 \mathrm{a}$ & 113 & $57.9 \pm 15.1 \mathrm{~cd}$ \\
\hline Chlorantraniliprole & 102 & IF & 106 & $88.4 \pm 4.0 \mathrm{~b}$ & 113 & $82.7 \pm 7.6 \mathrm{ab}$ \\
\hline Cyantraniliprole & 98 & IF & 98 & $74.6 \pm 7.8 \mathrm{c}$ & 128 & $71.3 \pm 7.5 \mathrm{c}$ \\
\hline Cyantraniliprole & 197 & IF & 109 & $98.1 \pm 1.2 \mathrm{a}$ & 152 & $76.2 \pm 9.6 b$ \\
\hline$F_{8,63}$ & & & & 25.90 & & 30.10 \\
\hline$P$ & & & & $<0.0001$ & & $<0.0001$ \\
\hline
\end{tabular}

Leaflets were collected at two times (bloom and early pod, 44 and $51 \mathrm{~d}$ after planting) in Geneva, NY, in 2009.

${ }^{a}$ Seed treatments ( $\mu \mathrm{g} \mathrm{AI} / \mathrm{seed}$ ) or in-furrow applications (g AI/ha).

${ }^{b}$ Seed treatment (ST), in-furrow (IF). 
the foliar application of chlorantraniliprole caused a significantly higher level of mortality than the in-furrow application of chlorantraniliprole and the untreated control (Table 8).

Overall, a high level of $O$. nubilalis larval mortality was achieved by administering chlorantraniliprole as a seed treatment, in-furrow treatment, and foliar spray. Results from the 2009 bioassay are particularly noteworthy because the high rate of chlorantraniliprole seed treatment ( $334 \mu \mathrm{g} \mathrm{AI} / \mathrm{seed}$ ) resulted in nearly 98 and $91 \%$ mortality of O. nubilalis larvae at bloom and early-pod formation, respectively. Similarly, in the same trial, the chlorantraniliprole seed treatment ( $334 \mu \mathrm{g} \mathrm{AI} / \mathrm{seed}$ ) reduced pod damage by $83 \%$ compared with the untreated control.

\section{Discussion}

Anthranilic diamide insecticides offer an alternative to neonicotinoid and pyrethroid insecticides for insect pest management in selected vegetable crops, but with a reduced risk of nontarget effects and environmental concerns. Our experiments demonstrated the clear success of chlorantraniliprole and cyantraniliprole for managing both $D$. platura and O. nubilalis in snap bean. Levels of pest control using certain formulations and rates of chlorantraniliprole and cyantraniliprole were equivalent to those provided by the industry standards when applied in a similar manner (i.e., seed treatment for D. platura control, and foliar application for O. nubilalis control). Additionally, we demonstrated that at-planting applications of chlorantraniliprole and cyantraniliprole as either seed or in-furrow treatments successfully reduced $O$. nubilalis damage. Taken together, our results indicate that a single at-planting application of an anthranilic diamide like chlorantraniliprole, especially delivered as a seed treatment, could effectively manage both D. platura and $O$. nubilalis, thereby reducing costs of production and environmental hazard.

For D. platura management, seed treatments and in-furrow applications were among both the best and worst treatment groups. In the 2009 trial, all treatments performed equally well (and better than the untreated control). In the 2010 trial, the higher rates within each $\mathrm{AI}$ and application method tended to provide the best control, but no AI or application method was clearly superior. Cyantraniliprole and chlorantraniliprole appear to be equally effective at reducing damage. This finding corroborates previous work by Palumbo (2011) where both AIs applied in-furrow reduced $D$.

Table 8. Percentage mortality ( \pm SE) of $O$. nubilalis neonates after $96 \mathrm{~h}$ when subjected to leaflets collected from snap bean field plantings treated with chlorantraniliprole $(74 \mathrm{~g} \mathrm{Al} / \mathrm{ha})$ administered as either an in-furrow treatment or foliar spray

\begin{tabular}{lccccc}
\hline $\begin{array}{l}\text { Application } \\
\text { type }{ }^{a}\end{array}$ & \multicolumn{2}{c}{ Bloom } & & \multicolumn{2}{c}{ Early pod } \\
\cline { 2 - 3 } \cline { 5 - 6 } & $\begin{array}{c}n \\
\text { subjects }\end{array}$ & $\begin{array}{c}\text { Percent } \\
\text { mortality }\end{array}$ & & $\begin{array}{c}n \\
\text { subjects }\end{array}$ & $\begin{array}{c}\text { Percent } \\
\text { mortality }\end{array}$ \\
\hline $\begin{array}{l}\text { Untreated } \\
\quad \text { control }\end{array}$ & 452 & $13.6 \pm 2.8 \mathrm{~b}$ & & 306 & $10.1 \pm 1.6 \mathrm{~b}$ \\
IF & 454 & $27.1 \pm 3.2 \mathrm{~b}$ & & 288 & $10.0 \pm 2.2 \mathrm{~b}$ \\
$\mathrm{~F}$ & 487 & $100.0 \pm 0.0 \mathrm{a}$ & & 301 & $80.2 \pm 4.2 \mathrm{a}$ \\
$F$ & & 11.94 & & 165.43 \\
df & & 2,90 & & 2,54 \\
$P$ & & $<0.0001$ & & $<0.0001$ \\
\hline
\end{tabular}

Leaflets were collected at two times (bloom and early pod, 49 and $56 \mathrm{~d}$ after planting) in Geneva, NY, in 2011.

${ }^{a}$ In-furrow (IF), foliar (F) platura damage to the same level as thiamethoxam ( $>70 \%$ seedling emergence at $22 \mathrm{~d}$ after planting).

Foliar spray applications of both diamides consistently achieved superior O. nubilalis control compared with the seed and in-furrow applications. However, this comparison does not necessarily reflect performance under natural field conditions. Applications were timed to precisely coincide with the artificial infestation of O. nubilalis (within $24 \mathrm{~h}$ ), which would not always occur within a population in a commercial field. More importantly, the artificial infestation created unrealistically high densities of $O$. nubilalis in order to more easily discern differences in mortality among treatments. Therefore, products that appeared to reduce damage to intermediate levels (i.e., between the foliar applications and the untreated control) may provide commercially acceptable control when used under normal field infestation levels. Of special note, one of the chlorantraniliprole seed treatments (Dermacor X-100, chlorantraniliprole $334 \mu \mathrm{g} \mathrm{AI}$ seed), provided near-perfect protection of plants and pods from $O$. nubilalis $(<1 \%$ damage for each; Table 4$)$. Similar to the results with $D$. platura, no clear superiority was exhibited by either seed treatments or in-furrow spray applications for reducing O. nubilalis damage. However, chlorantraniliprole treatments reduced damage more than equivalent rates and methods of cyantraniliprole treatments (for seed and in-furrow treatments). Superior control by chlorantraniliprole (compared to cyantraniliprole) has also been reported in laboratory bioassays of another lepidopteran pest, $S$. frugiperda, and is potentially explained by the lower water solubility of chlorantraniliprole (Thrash et al. 2013). In that assay, the lower survivorship in chlorantraniliprole treatments was seen in both the vegetative (V3) and reproductive (R6) stages of seed-treated soybean. Based on the field results, we conclude that the higher rates of chlorantraniliprole applied as a seed treatment or in-furrow spray would likely provide effective, simultaneous control of $D$. platura and O. nubilalis.

In our study, the 2009 bioassay results mirrored the findings in the field. Treatments that substantially reduced $O$. nubilalis damage also resulted in higher neonate mortality (Tables 4 and 7). The highest rates of chlorantraniliprole (seed or in-furrow) resulted in very high mortality during the later (early pod) bioassay, demonstrating the long residuals of these treatments. In the 2011 trial, results from bioassays and field experiments did not correspond as well as in the previous season. Chlorantraniliprole treatments exhibited low mortality of $\mathrm{O}$. nubilalis in the laboratory; however, in the field, even the lowest rate of chlorantraniliprole decreased plant and pod damage relative to the untreated control (Tables 6 and 8). Our experiments were not designed to determine the cause of differences between the laboratory and field results, but the reduction in feeding caused by chlorantraniliprole may explain reduced damage in the field despite low mortality in the bioassay (Hannig et al. 2009). This highlights the importance of assessing pesticides in both the laboratory and field in order to determine actual efficacy. More importantly, this may demonstrate an additional cause of the efficacy of the anthranilic diamides; applications halt feeding even before mortality occurs, resulting in substantially reduced damage.

The ability of the anthranilic diamides to control E. fabae, which is another important pest of snap bean in the midwestern and eastern United States, was not evaluated in our studies. Empoasca fabae can cause damage throughout the season, but has the greatest potential to harm snap bean seedlings (Flood and Wyman 2005). Feeding may cause stunting and hopperburn, resulting in reduced pod yields (Flood and Wyman 2005). This pest is managed using either thiamethoxam seed treatment or foliar pyrethroid insecticides like bifenthrin. Thus, the insecticides snap bean growers typically use to manage D. platura 
and O. nubilalis also control E. fabae (Flood and Wyman 2005, Cornell Cooperative Extension 2015). Our study fields did not have high enough $E$. fabae populations to evaluate performance of the anthranilic diamides. Previous work suggested that cyantraniliprole applied as a seed treatment or in-furrow treatment would provide mediocre E. fabae control, although this study was conducted in potato (Groves et al. 2013). It is possible that other formulations and rates of cyantraniliprole could successfully manage this pest, especially given its ability to control other hemipterans (Natwick 2012a,b, Tiwari and Stelinski 2012, Barry et al. 2015). No equivalent study has been conducted with chlorantraniliprole, which is known to have little efficacy against sucking pests (Barry et al. 2015). Future integrated pest management programs using at-plant anthranilic diamide treatments should consider the historical E. fabae pressure in a given area and adapt accordingly to prevent damage.

In conclusion, the application of an anthranilic diamide at planting has both economic and environmental benefits for commercial vegetable production. Growers could reduce the number of insecticide applications needed to control key insect pests by making a single application at planting, thereby reducing the amount of labor, fuel, and other costs associated with foliar pesticide applications. A seed treatment option would be ideal because it requires no additional resources at planting (e.g., water hauled by the tractor) and further minimizes contact by the applicator (e.g., no mixing). The substitution of anthranilic diamides in place of broader spectrum insecticides would reduce the disruption of naturally occurring biological control organisms and conserve pollinators. These advantages will be increasingly important as older materials lose registrations or experience pest resistance issues. Exploring multiple methods of application for newly developed materials is critical for developing innovative pest management programs that require minimal pesticide use.

\section{Acknowledgments}

We gratefully acknowledge A. Taylor (Professor, Cornell University) for treating seeds with insecticides in 2009. Technical support was also greatly appreciated by the following: D. Artz, R. Austin, M. Bekauri, M. Campo, K. Cappiello, T. Castle, J. Colon, A. daSilva, E. Fok, M. Garlick, M. Hessney, E. Maloney, J. Petzoldt, E. Smith, and A. Yost. We also thank G. Hannig and H. Portillo for reviewing an earlier draft of this paper. This research was funded by the New York State Vegetable Research Council and DuPont Crop Protection.

\section{References Cited}

Alyokhin, A., G. Dively, M. Patterson, C. Castaldo, D. Rogers, M. Mahoney, and J. Wollam. 2007. Resistance and cross-resistance to imidacloprid and thiamethoxam in the Colorado potato beetle. Pest Manage. Sci. 63: 32-41.

Anderson, R. L. 1982. Toxicity of fenvalerate and permethrin to several nontarget aquatic invertebrates. Environ. Entomol. 11: 1251-1257.

Antwi, F. B., and G.V.P. Reddy. 2015. Toxicological effects of pyrethroids on non-target aquatic insects. Environ. Toxicol. Pharmacol. 40: 915-923.

Barry, J. D., H. E. Portillo, I. B. Annan, R. A. Cameron, D. G. Clagg, R. F. Dietrich, L. J. Watson, R. M. Leighty, D. L. Ryan, J. A. McMillan, et al. 2015. Movement of cyantraniliprole in plants after foliar applications and its impact on the control of sucking and chewing insects. Pest Manage. Sci. 71: 395-403.

Beers, E. H., and R. A. Schmidt. 2014. Impacts of orchard pesticides on Galendromus occidentalis: lethal and sublethal effects. Crop Prot. 56: 16-24.

Beers, E. H., J. F. Brunner, J. E. Dunley, M. Doerr, and K. Granger. 2005. Role of neonicotinyl insecticides in Washington apple integrated pest management. Part II. Nontarget effects on integrated mite control. J. Insect Sci. 5: 16 .
Bonmatin, J. M., C. Giorio, V. Girolami, D. Goulson, D. P. Kreutzweiser, C. Krupke, M. Liess, E. Long, M. Marzaro, E.A.D. Mitchell, et al. 2015. Environmental fate and exposure; neonicotinoids and fipronil. Environ. Sci. Pollut. Res. Int. 22: 35-67.

Brugger, K. E., P. G. Cole, I. C. Newman, N. Parker, B. Scholz, P. Suvagia, G. Walker, and T. G. Hammond. 2010. Selectivity of chlorantraniliprole to parasitoid wasps. Pest Manage. Sci. 66: 1075-1081.

Caballero, R., D. J. Schuster, N. A. Peres, J. Mangandi, T. Hasing, F. Trexler, S. Kalb, H. E. Portillo, P. C. Marçon, and I. B. Annan. 2015. Effectiveness of cyantraniliprole for managing Bemisia tabaci (Hempitera: Aleyrodidae) and interfering with transmission of tomato yellow leaf curl virus on tomato. J. Econ. Entomol. 108: 894-903.

Cornell Cooperative Extension 2015. Beans - dry, snap, and lima, pp. 87-114. In Reiners S., and A. Seaman (eds.), 2016 Cornell integrated crop and pest management guidelines for commercial vegetable production. Cornell Cooperative Extension, Ithaca, NY.

Croft, B. A. 1990. Pesticide selectivity: Pyrethroids, pp. 335-353. Arthropod biological control agents and pesticides. John Wiley \& Sons, New York, NY.

Decourtye, A., and J. Devillers. 2010. Ecotoxicity of neonicotinoid insecticides to bees, pp. 85-95. In S. H. Thany (ed.), Insect nicotinic acetylcholine receptors. Springer, New York, NY.

Desneux, N., A. Decourtye, and J. M. Delpuech. 2007. The sublethal effects of pesticides on beneficial arthropods. Ann. Rev. Entomol. 52: 81-106.

Dinter, A., and A. Samel. 2014. Cyantraniliprole: pollinator profile of the novel insecticides under laboratory, semi-field and field conditions, pp. 28-49. In P. A. Oomen and J. Pistorius (eds.), Proceedings, 12th International Symposium of the ICP-PR Bee Protection Group, 15-17 September, Julius Kühn-Institut, Ghent, Belgium.

Dinter, A., K. Brugger, N. M. Frost, and M. D. Woodward. 2008a. Chlorantraniliprole (Rynaxypyr): A novel DuPont ${ }^{\mathrm{TM}}$ insecticide with low toxicity and low risk for honey bees (Apis mellifera) and bumble bees (Bombus terrestris) providing excellent tools for uses in integrated pest management pp. 84-96. In P. A. Oomen and H. M. Thompson (eds.), Proceedings, 10th International Symposium of the ICP-Bee Protection Group, 8-10 October, Julius Kühn-Institut, Bucharest, Romania.

Dinter, A., K. Brugger, A. Bassie, N. M. Frost, and M. D. Woodward. 2008b. Chlorantraniliprole (DPX-E2Y45, DuPont ${ }^{\mathrm{TM}}$ Rynaxypyr ${ }^{\circledR}$, Coragen ${ }^{\circledR}$ and Altacor ${ }^{\circledR}$ insecticide) - a novel anthranilic diamide insecticide - demonstrating low toxicity and low risk for beneficial insects and predatory mites. IOBC WPRS Bull. 35: 128-135.

Dinter, A., A. Samel, N. M. Frost, and F. L. Groya. 2012. Cyantraniliprole (DPXHGW86, DuPont ${ }^{\mathrm{TM}}$ Cyazypyr ${ }^{\mathrm{TM}}$ ) - a novel DuPont insecticide with selectivity towards beneficial non-target arthropods. IOBC WPRS Bull. 82: 9-14.

Dively, G. P., and J. E. McCully. 1979. Nature and distribution of European corn borer feeding injury on snap beans. J. Econ. Entomol. 72: 152-154.

Douglas, M. R., J. R. Rohr, and J. F. Tooker. 2015. Neonicotinoid insecticide travels through a soil food chain, disrupting biological control of non-target pests and decreasing soya bean yield. J. Appl. Ecol. 52: 250-260.

DuPont 2008. Coragen insect control. Coragen Technical Bulletin Reorder No.: K-14833.

Eckenrode, C. J., and D. R. Webb. 1989. Establishment of various European corn borer (Lepidoptera: Pyralidae) races on selected cultivars of snap beans. J. Econ. Entomol. 82: 1169-1173.

Flood, B. R., and J. A. Wyman. 2005. Beans, pp. 64-81. In R. Foster, and B. R. Flood (eds.), Vegetable insect management. Miester Media Worldwide, Wiloughby, OH.

Foster, R., and B. R. Flood. 2005. Vegetable insect management. Meister Media Worldwide, Willoughby, OH.

Gerson, U., and E. Cohen. 1989. Resurgences of spider mites (Acari: Tetranychidae) induced by synthetic pyrethroids. Exp. Appl. Acarol. 6: $29-46$.

Gibbons, D., C. A. Morrissey, and P. Mineau. 2015. A review of the direct and indirect effects of neonicotinoids and fipronil on vertebrate wildlife. Environ. Sci. Pollut. Res. 22: 103-118.

Godfray, H.C.J., T. Blacquière, L. M. Field, R. S. Hails, G. Petrokofsky, S. G. Potts, N. E. Raine, A. J. Vanbergen, A. R. McLean. 2014. A restatement of the natural science evidence base concerning neonicotinoid insecticides and insect pollinators. Proc. R. Soc. B. 281: 20140558. 
Goulson, D. 2013. Review: An overview of the environmental risks posed by neonicotinoid insecticides. J. Appl. Ecol. 20: 977-987.

Gradish, A. E., C. D. Scott-Dupree, L. Shipp, C. R. Harris, and G. Ferguson. 2009. Effect of reduced risk pesticides for use in greenhouse vegetable production on Bombus impatiens (Hymenoptera: Apidae). Pest Manage. Sci. 66: 142-146.

Gradish, A. E., C. Scott-Dupree, L. Shipp, C. R. Harris, and G. Ferguson. 2010. Effect of reduced risk pesticides on greenhouse vegetable arthropod biological control agents. Pest Manage. Sci. 67: 82-86.

Groves, R. L., S. Chapman, K. E. Frost, A. S. Huseth, and C. L. Groves. 2013. Use of systemic insecticides to control Colorado potato beetle and potato leafhopper, 2012. Arthropod Manage. Tests 38: E52.

Hannig, G. T., M. Ziegler, and P. G. Marçon. 2009. Feeding cessation effects of chlorantraniliprole, a new anthranilic diamide insecticide, in comparison with several insecticides in distinct chemical classes and mode-of-action groups. Pest Manage. Sci. 65: 969-974.

Hardke, J. T., J. H. Temple, B. R. Leonard, and R. E. Jackson. 2011. Laboratory toxicity and field efficacy of selected insecticides against fall armyworm (Lepidoptera: Noctuidae). Fla. Entomol. 94: 272-278.

Haya, K. 1989. Toxicity of pyrethroid insecticides to fish. Environ. Toxicol. Chem. 8: 381-391.

Houndété, T., G. Kétoh, O. S. Hema, T. Brévault, I. A. Glitho, and T. Martin. 2010. Insecticide resistance in field populations of Bemisia tabaci (Hemiptera: Aleyrodidae) in West Africa. Pest Manage. Sci. 66: 1181-1185.

Hull, L. A., and V. R. Starner. 1983. Impact of four synthetic pyrethroids on major natural enemies and pests of apple in Pennsylvania. J. Econ. Entomol. 76: 122-130.

Huseth, A. S., R. L. Groves, S. A. Chapman, and B. A. Nault. 2015 a. Evaluation of diamide insecticdes co-applied with other agrochemicals at various times to manage Ostrinia nubilalis in processing snap bean. Pest Manage. Sci. 71: 1649-1656.

Huseth, A. S., J. Petersen, K. Poveda, Z. Szendrei, B. A. Nault, G. K. Kennedy, and R. L. Groves. 2015b. Spatial and temporal potato intesification drives insecticide resistance in the specialist herbivore, Leptinotarsa decemlineata. PLoS ONE 10: e0127576.

Hutchison, W. D., B. Flood, and J. A. Wyman. 2004. Advances in United States sweet corn and snap bean insect pest management, pp. 247-278. In A. R. Horowitz, and I. Ishaaya (eds.), Insect pest management: field and protected crops. Springer-Verlag, Berlin, Germany.

Inglesfield, C. 1989. Pyrethroids and terrestrial non-target organisms. Pestic. Sci. 27: 387-428.

Jacobson, A., R. Foster, C. Krupke, W. Hutchison, B. Pittendrigh, and R. Weinzierl. 2009. Resistance to pyrethroid insecticides in Helicoverpa zea (Lepidoptera: Noctuidae) in Indiana and Illinois. J. Econ. Entomol. 102: 2289-2295.

Jeanguenat, A. 2013. The story of a new insecticidal chemistry class: the diamides. Pest Manage. Sci. 69: 7-14.

Judge, F. D., and F. L. McEwen. 1970. Field testing candidate insecticides as seed treatments for control of the seed-corn maggot on lima beans in New York State. J. Econ. Entomol. 63: 1332-1333.

Kranthi, K. R., D. Jadhav, R. Wanjari, S. Kranthi, and D. Russell. 2001. Pyrethroid resistance and mechanisms of resistance in field strains of Helicoverpa armigera (Lepidoptera: Noctuidae). J. Econ. Entomol. 94: 253-263.

Kuhar, T. P., J. F. Walgenbach, and H. B. Doughty. 2010. Control of Helicoverpa zea in tomatoes with chlorantraniliprole applied through drip chemigation. Plant Health Prog. Online: PHP-2009-0407-2001-RS.

Lanka, S. K. 2014. Activity of chlorantraniliprole and thiamethoxam seed treatments on life stages of the rice water weevil as affected by the distribution of insecticides in rice plants. Pest Manage. Sci. 70: 338-344.

Lanka, S. K., J. A. Ottea, J. M. Beuzelin, and M. J. Stout. 2013a. Effects of chlorantraniliprole and thimethoxam rice seed treatments on egg numbers and first instar survival of Lissorhoptrus oryzophilus (Coleoptera: Curculionidae). J. Econ. Entomol. 106: 181-188.

Lanka, S. K., J. A. Ottea, J. A. Davis, A. B. Hernandez, and M. J. Stout. 2013b. Systemic effects of thiamethoxam and chlorantraniliprole seed treatments on adult Lissorhoptrus oryzophilus (Coleoptera: Curculionidae) in rice. Pest Manage. Sci. 69: 250-256.

Larson, J. L., C. T. Redmond, and D. A. Potter. 2012. Comparative impact of an anthranilic diamide and other insecticidal chemistries on beneficial invertebrates and ecosystem services in turfgrass. Pest Manage. Sci. 68:

Liu, M. Y., T. J. Tzeng, and C. N. Sun. 1981. Diamondback moth resistance to several synthetic pyrethroids. J. Econ. Entomol. 74: 393-396.

Natwick, E. T. 2012a. Cyazypyr efficacy against brocolli insects, 2011. Arthropod Manage. Tests 37: E7.

Natwick, E. T. 2012b. Cyazypyr efficacy against lettuce insects, 2011. Arthropod Manag. Tests 37: E27.

Palumbo, J. C. 2011. Seed corn maggot control with in-furrow sprays and seed treatments on cantaloupes, 2010. Arthropod Manage. Tests 36: E23.

Pisa, L. W., V. Amaral-Rogers, L. P. Belzunces, J. M. Bonmatin, C. A. Downs, D. Goulson, D. P. Kreutzweiser, C. Krupke, M. Liess, M. McField, et al. 2015. Effects of neonicotinoids and fipronil on non-target invertebrates. Environ. Sci. Pollut. Res. 22: 68-102.

Pluciennik, Z. 2012. The modern insecticide (chlorantraniliprole) used to control codling moth (Cydia pomonella L.). J. Fruit Ornam. Plant Res. 20: $85-89$.

Rajavel, D. S., A. Mohanraj, and K. Bharathi. 2011. Efficacy of chlorantraniliprole (Coragen 20SC) against brinjal shoot and fruit borer, Leucinodes orbonalis (Guen.). Pest Manage. Hort. Ecosyst. 17: 28-31.

Reid, W. J. 1940. Biology of the seed corn maggot in the coastal plain of the South Atlantic States. USDA Agric. Tech. Bull. 723: 1-43.

Reiners, S., and A. Seaman. 2015. 2016 Cornell integrated crop and pest management guidlines for commercial vegetable production. Cornell Cooperative Extension, Ithaca, NY.

Sanborn, S. M., J. A. Wyman, and R. K. Chapman. 1982. Studies on the European corn borer in relation to its management on snap beans. J. Econ. Entomol. 75: 551-555.

SAS Institute 2016. SAS/Stat User's Guide, Version 9.4. Cary, NC.

Shelton, A. M., B. A. Nault, J. Plate, and J. Z. Zhao. 2003. Regional and temporal variation in susceptibility to $\lambda$-cyhalothrin in onion thrips, Thrips tabaci (Thysanoptera: Thripidae), in onion fields in New York. J. Econ. Entomol. 96: 1843-1848.

Sidhu, J. K., J. T. Hardke, and M. Stout. 2014. Efficacy of Dermacor-X-100® seed treatment against Diatraea saccharalis (Lepidoptera: Crambidae) on rice. Fla. Entomol. 97: 224-232.

Smith, T. M., and G. W. Stratton. 1986. Effects of synthetic pyrethroid insectides on nontarget organisms, pp. 93-120. In F. A. Gunther (ed.), Residue reviews. Springer, New York, NY.

Theiling, K. M., and B. A. Croft. 1988. Pesticide side-effects on arthropod natural enemies: A database summary. Agric. Ecosyst. Environ. 21: 191-218.

Thrash, B., J. J. Adamczyk, J. G. Lorenz, A. W. Scott, J. S. Armstron, R. Pfannenstiel, N. Taillon. 2013. Laboratory evaluations of lepidopteranactive soybean seed treatments on survivorship of fall armyworm (Lepidoptera: Noctuidae) larvae. Fla. Entomol. 96: 724-728.

Tiwari, S., and L. L. Stelinski. 2012. Effects of cyantraniliprole, a novel anthranilic diamide insecticide, against Asian citrus psyllid under laboratory and field conditions. Pest Manage. Sci. 69: 1066-1072.

Vea, E. V., and C. J. Eckenrode. 1976. Seed maggot injury on surviving bean seedlings influences yield. J. Econ. Entomol. 69: 545-547.

Wang, J., Y. Li, Z. Han, Y. Zhu, Z. Xie, J. Wang, Y. Liu, and X. Li. 2012. Molecular characterization of a ryanodine receptor gene in the rice leaffolder, Cnaphalocrocis medinalis (Guenée). PLoS ONE 7: e36623.

Whalen, R. A., D. A. Herbert, S. Malone, T. P. Kuhar, C. C. Brewster, and D. D. Reisig. 2016. Effects of diamide insecticides on predators in soybean. J. Econ. Entomol. pii: tow173.

Younas, A., Z. Khan, W. Wakil, M. Shaaban, and S. M. Prager. 2016. The efficacy of Beauveria bassiana, jasmonic acid and chlorantraniliprole on larval populations of Helicoverpa armigera in chickpea crop ecosystems. Pest Manage. Sci. DOI: 10.1002/ps.4297.

Yu, S. J. 2015. Mode of action of insecticides, pp. 133-174. The toxicology and biochemistry of insecticides. Taylor \& Francis Group, Boca Raton, FL. 